\title{
Farmers Response on Government Policy in Soybean UPSUS
}

\author{
Jati Nurcholis ${ }^{1}$, Tandi Balla ${ }^{2}$, Tandi Balla ${ }^{3}$, Ezra Artasastah ${ }^{4}$, M Chairulbasrun Umanailo 5 \\ 1,2,3,4 Agricultural Development Polytechnic of Gowa, Indonesia \\ ${ }^{5}$ Universitas Iqra Buru \\ 1jatinurcholis81@gmail.com
}

\begin{abstract}
The increase in production of rice commodities, corn, and soy (Pajale) continues to be encouraged by the Government to provide adequate needs to avoid exports. This Program has been conducted intensively on the activities of the state BUDGET-year 2017. The purpose of this research is 1) to know the response of farmers to the soy UPSUS program, and 2) to know the income received by farmers in the soybean UPSUS Program. The method of research is conducted using survey method, the form of primary data collection by providing questions to the respondent, hereinafter, to know the level of admission of soybean farming is done using R/C ratio analysis. As the results, the average age of farmers in productive age (45), all farmers have participated in formal education, and among them, there are 17 people at basic educated. Mostly there are three people as Family members. Experience farming range between 26 and 32 years, and the area of land tenure $>=1.7$ ha. Revenue acquisition of farmers Upsus in the 1-time production process (on average four months) obtained a net profit of IDR 4.960.000, -with R/C Ratio acquired the value of 2.03 , which means that soybean cultivation deserves to cultivate
\end{abstract}

Keywords

Farmers, Government, Land, Agriculture

Article Received: 10 August 2020, Revised: 25 October 2020, Accepted: 18 November 2020

\section{Introduction}

UPSUS Program (Special Efforts) is an effort to support soy self-sufficiency. Upsus activities carried out not only role as bodyguards and safeguard the distribution of seeds, fertilizers, and alsintan course, but besides, it also oversees the movement to repair irrigation networks, systems simultaneous planting, and control of Plant Pests (OPT). UPSUS also plays a role in accelerating the adoption of improved technology rice (Hannah et al., 2013; Umanailo, Yulisvestra, Oki, Mulyasari, \& Ridwan, 2019), corn and soybean production through the Management Implementation Movement Integrated Crops (GP-PTT), Expansion of Planting Areas (PAT), and land optimization (Arikunto, 2012).

Upsus program is held simultaneously in several provinces in Indonesia, namely North Sumatra, South Sulawesi, Jambi, West Kalimantan, Kalimantan South, Central Kalimantan, Central Java and East Java (Alyas. Muhammad Rakib, 2017) When viewed from the productivity of soybean plants in the Regency in Jambi Province, then East Tanjung Jabung Regency is the third-largest contributor with a total soybean production of 1.028 tons productivity of 1.508 tons/ha. This productivity value is higher compared to the productivity of Jambi Province which is 1.372 tons/ha, this is due to the East Tanjung Jabung Regency is one Soybean production centres in Jambi Province with high land use (Devi Juwaheer, Pudaruth, \& Monique Emmanuelle Noyaux, 2012; Hannah et al., 2013).

Efforts to increase food productivity continue to be carried out, one of which is through a newly launched program, namely Special Efforts for Rice, Corn, Soybean (UPSUS PAJALE). Through UPSUS PAJALE activities, it is expected to become a platform for farmers to apply various farming technologies provided to achieve pagan selfsufficiency goals, one of which is soybean commodity (Rachman, Hamiru, Umanailo, Yulismayanti, \& Harziko,
2019; Rahmat, Gs, Djafri, Shofwan, \& Umanailo, 2019). The efforts to increase food production from each commodity continue to meet the adequacy of products that become community needs (Zhong, Huang, Zhang, \& Wang, 2011). Therefore, there is no less importance in realizing self-sufficiency for soy commodities in 2020. In line with that, the Ministry of Agriculture through the extraordinary efforts Program (Upsus) has encouraged the achievement of soybean self-sufficiency by spur cropping intensified through the program of APBN-P year 2017, which focused on strengthening the growth of strategic food commodity is one of the food crops (soy).

Currently, the availability of soy is still very dependent on imports, so that the volatility of supply and prices in the international market directly affects the turmoil in the country. Based on the BPS data (2017)(El Bilali, Bassole, Dambo, \& Berjan, 2020; Muller et al., 2017), the total import of this commodity was 207.8 thousand tonnes with a value of US \$92.6 million in April 2017 experienced an increase by volume to 242.2 thousand tonnes with a value of US \$108.0 million (Hannah et al., 2013; Umanailo, 2020a; Zhong et al., 2011). The vast Data of the harvest, production, and the quality of soybean crop is five years (2013 to 2017) for the provinces of South Sulawesi and Indonesia, as follows

\section{Method}

Place and Time 
The research activities conducted in Sambueja village, Simbang subdistrict, Maros Regency, which is approximately $45 \mathrm{~km}$ from Makassar city or $15 \mathrm{~km}$ from the capital of Maros Regency. The topographical conditions of this area are relatively flat and are at an altitude of 10-100 m above sea level (DPL). Considerations in the selection of research locations include:

One of the areas that implement the Upsus Pajale Program.

The land used as a soybean crop had previously planted with soybean plants, and the topography is relatively flat until wavy.

People make soybean crops as alternative food commodities in addition to leading food such as rice and corn.

The community that cultivating soy plants has not done the calculation of outputs and inputs that exist in the venture.

Research is conducted using the survey method, which is the primary data collection by providing questions to the respondent (Creswell, 2013).

The research activity lasted for four months, starting from July 26th to November 26th, 2019, according to the research permit from the Investment Office and integrated service of one door, the government of Maros District.

\section{Data Types and Sources}

The types and sources of data used in this study consist of primary data and secondary data. Primary data in the form of qualitative data obtained from interviews with respondents. Qualitative data collection used informants that can provide information about the activities of soybean Upsus (Chen et al., 2011; Tilman, Balzer, Hill, \& Befort, 2011; Zhang et al., 2015). The interview process is done intensively until the data obtained at the adequacy level. In the process of collecting data is also practised principles of data triangulation. Besides, there is also data verification along with the extension coordinator of the Simbang subdistrict by using FGD (focus group discussion) method. Secondary data as supporting data, collected from related services, reporting, and documents on various sources that support this research activity. The secondary data collected is sourced from the Central statistical Body (BPS), the monographic data, local government regulations/policies, and relevant libraries.

\section{Population and Samples}

The population in this study is farmers who cultivate soybean plants and reside in research locations.

Sampling was done intentionally (purposive sampling), taking samples by 10 percent of the population (Ponto, Benu, \& Kumaat, 2017) Sampling chose because the population is determined by farmers who cultivate soybean plants and engage in soybean Upsus activities (Tahir \& Umanailo, 2019; Umanailo \& Ali, 2019; Zhong et al., 2011).

\section{Data collection techniques}

Observation, which is data collection through direct observation of the condition of the research object, covering the physical condition of the land, source of production facilities, cultivation process, harvest, and post-harvest.
Interviews, i.e., collecting data through meetings to dig information to respondents during the research activities. Documentation, that is, a data retrieval that is relevant to the research available to the institution or related institutions and shooting in the field (photoshoot).

\section{Data analysis techniques}

Data analysis based on the existing conditions and types of data, further interpretation with the purpose of the research conducted (Dayan, Cantrell, \& Duke, 2009; Palacios-Lopez, Christiaensen, \& Kilic, 2017). The Data obtained is included in tabulation, then analyzed in a qualitative descriptive (Romlah, Pratiwi, Indah, \& Umanailo, 2020; Zhao \& Hannum, 2019).

Furthermore, to determine the level of acceptance of soybean farming is carried out using the $\mathrm{R} / \mathrm{C}$ ratio analysis (Return Cost Ratio) is the ratio between revenue and cost. The statement can express in the following formula: $\mathrm{A}=\mathrm{Py}$ $\mathrm{x} \mathrm{Y} /(\mathrm{FC}+\mathrm{VC})$

Where:

$\mathrm{A}=\mathrm{R} / \mathrm{C}$ ratio

$\mathrm{R}=$ Revenue

$\mathrm{C}=$ Cost

Py $=$ Output Price

$\mathrm{Y}=$ output

$\mathrm{FC}=$ Fixed Cost

$\mathrm{VC}=$ Variable Cost

Decision criteria:

$\mathrm{R} / \mathrm{C}$ ratio $>1$ profit

$\mathrm{R} / \mathrm{C}$ ratio of $<1$ loss farming

$\mathrm{R} / \mathrm{C}$ ratio $=1$ farming breakeven (no profit/no loss)

\section{Results and Discussions}

\section{Characteristics of respondent farmers}

Age of farmers; The average age of farmers began to devote his time to farming activities was 45.23 years, classified as a productive age; And a spread of age between 24 S. D 64 years.

Education level; All the respondents were 30 people (100\%) have participated in formal education, and there were 17 people $(56.67 \%)$ Basic educated. In transferring technology, innovation needs to conduct intensive guidance.

Total family Liabilities; The family members-owned by most respondents were three people, amounting to 14 people $(46.67 \%)$. The existence of this family member is generally helpful in maintenance activities, such as fertilization, and pest/disease control; While planting and harvesting activities, still, use labour from outside the family (in the form of wholesale work).

Farming experience; Most experience farming from the farmer respondents, the range is between 26 years and more than 32 years, which is 16 people $(53.33 \%)$. Farming experience is very influential in decision making for farmers in managing their efforts.

Land; The area of land that manages by the farmers of the respondents most is on the land area $>=1.7$ ha managed by 11 respondent farmers $(36.66 \%)$.

Farmer's response to Government policy in Soy Upsus 
Food problems, especially soybeans, have received the attention of the government through the Ministry of Agriculture to increase their productivity to reduce soybean imports. As stated by the Head of the Department of Agriculture and Food Security of Maros Regency (Ir. Nurdin, M.Sc) that:

The choice of location for soybean planting adjusted to the agro-climate conditions and mastery of farmers' technology in cultivating soybeans. Also, the buyers of soybean production already know Simbang District as the centre of soybean production for Maros Regency.

Soybean production achieved by soybean farmers who currently grow Argomulyo Varieties an average of 1.5 tons per hectare, is still below the average production of 2 tons per hectare. thus, changes need to be made, among others: a) improvement of technical farming culture, b) empowerment of farmer groups through mentoring activities, and c) make a demonstration plot so farmers can see the results directly (Primary data, Processed 2020)

\section{Soybean production improvement program}

The implementation of the Upsus Pajale Program results has not been encouraging because its productivity is still far below the yield potential. After all, the average yield has only reached 1.5 tons per hectare from the potential yield of up to 2 tons per hectare.

Failure to achieve maximum results is caused by, among others, the use of production facilities in the form of fertilizers that are not by local recommendations, and the number of pests that attack crops, especially in the generative phase.

The results of interviews with extension workers (Nurdin, A.Md) and farmers (H. Dg. Gassing) said that:

'Soybean varieties cultivated by farmers participating in UPSUS Pajale are Anjasmoro (early maturity varieties) aged approximately 92 days, and the number of seeds used ranges from $40 \mathrm{~kg}$ per hectare. Argomulyo's production reaches an average of 1.5 tons per hectare. In the process of cultivation, plants rarely use SP fertilizer, NPK rarely used, not used urea because it causes plants to fall quickly. Besides, the insecticides used include Dusrband 200 EC and Dharmabas 500 EC. Farmers also carry out technical culture control of pests, for example, so that plants avoid pod attack borer, soybean planting should be done not later than mid-August (Primary Data after processing, 2019).'

Furthermore, the implementation of the duties of the instructors carried out following the counselling program contained in the annual work plan (RKTP). As the results of the interview conducted with Rukiah Astrida, S.TP (Simbang District Counseling Coordinator), that:

'The guidance system for extension workers ignores Permentan Number 82 of 2013, namely the Practice System (Training and Visitation), which in their visits is active per the compiled RKTP, and the material adjusted to the conditions in the field. The guidance system for farmers is carried out by visiting instructors through participatory methods of guiding and assisting farmers/farmer groups. Visiting activities began Monday to Wednesday, and on Thursday, they gathered at the BPP to conduct meetings, report on the results of the visit, and solve problems they found in the field. (Primary Data, Processed 2020).'

\section{Attitudes of Farmers Participating in Upsus Soybean}

Soybean cultivation activities have generally been carried out for a long time by farmers in Sambueja Village, Simbang District. They did cultivation because a) soybean cultivation did not have many activities; b) the income was sufficient to increase family income, c) and did not require much labour in the process of growth.

Cost Analysis of Soybean Planting Business 
This financing analysis is needed as one of the interests of farmers as soybean farmers so that the benefits they get can make them respond positively.

Analysis of the cost of income earned on soybean plantations carried out by farmers on 1 hectare of planted land is carried out using $\mathrm{R} / \mathrm{C}$ ratio analysis, as follows:

\begin{tabular}{|c|c|c|c|}
\hline Description & Number (unit) & $\begin{array}{l}\text { Price per unit } \\
\text { (IDR) }\end{array}$ & Total(IDR) \\
\hline $\begin{array}{l}\text { A. Fixed Cost (FC) } \\
\text { 1. property tax }\end{array}$ & 1 ha & 300.000 & $300.000,-$ \\
\hline Total (A) & & & $300.000,-$ \\
\hline \multicolumn{4}{|l|}{$\begin{array}{l}\text { B. Variable cost }(\mathrm{VC}) \\
\text { 1. wages for workers (part-time) }\end{array}$} \\
\hline a. Land processing & 1 kali & $1.500 .000,-$ & 1.500 .000 , \\
\hline b. Planting & $8 \mathrm{OH}$ & $100.000,-$ & $800.000,-$ \\
\hline c. Maintenance & $6 \mathrm{OH}$ & 100.000 & 600.000 ,- \\
\hline d. Harvest & $8 \mathrm{OH}$ & 100.000 & $800.000,-$ \\
\hline \multicolumn{4}{|l|}{ 2.Production facilities(fertilizer) } \\
\hline $\begin{array}{l}\text { a. Urea fertilizer } \\
\text { b. SP36 Fertilizer }\end{array}$ & - & - & \\
\hline c. Phonska Fertilizer & $100 \mathrm{~kg}$ & $2.300,-$ & $230.000,-$ \\
\hline 3. Means of production (herbicides) & & & \\
\hline $\begin{array}{l}\text { - Supretox } 276 \text { SL } \\
\text { 4. Means of production (insecticide) }\end{array}$ & 41 & $70.000,-$ & 280.000 ,- \\
\hline a. Dursban $200 \mathrm{EC}$ & 21 & 70.000 ,- & 140.000 ,- \\
\hline b. Dharmabas $500 \mathrm{EC}$ & 21 & $70.000,-$ & $140.000,-$ \\
\hline Description & units & $\begin{array}{c}- \\
\text { Price/unit } \\
\text { (@IDR) }\end{array}$ & $\begin{array}{l}\quad 4.490 .000,- \\
\text { total } \\
\text { (IDR) }\end{array}$ \\
\hline Total cost $(\mathrm{A}+\mathrm{B})$ & & & $4.790 .000,-$ \\
\hline C. Soybean sales to & $1.500 \mathrm{~kg}$ & $6.500,-$ & $9.750 .000,-$ \\
\hline D. Local Trader & - & - & 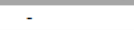 \\
\hline E. Gross profit & $=$ & - & 4.960 .000 \\
\hline
\end{tabular}

The income of farmers participating in Upsus Soybean activities in Sambueja Village, Simbang District in a single production process (an average of 4 months) obtained a net profit of Rp 4,960,000.

The $\mathrm{R} / \mathrm{C}$ analysis results obtained a value of 2.03 which means that the soybean cultivation by Upsus participating farmers in Sambueja Village, Simbang District is feasible.

\section{Conclusion}

Farmers ' response to the soybean Upsus Program is caused by, ease of obtaining seeds, technology mastery, lightweight financing, and ease in marketing results. 2. Based on the results of the analysis of $\mathrm{R} / \mathrm{C}$ ratio obtained, a value of 2.03 means soybean cultivation carried out by farmer Upsus qualified to be cultivated in Sambueja village, Simbang subdistrict

\section{References}

[1] Alyas. Muhammad Rakib. (2017). Strategi Pengembangan Usaha Mikro, Kecil Dan Menengah Dalam Penguatan Ekonomi Kerakyatan (Studi Kasus pada Usaha Roti Maros di Kabupaten Maros). Sosiohumaniora.

[2] Arikunto, S. (2012). Prosedur Penelitian: Suatu Pendekatan Praktik (Edisi Revisi). In Rineka Cipta.

[3] Chen, X. P., Cui, Z. L., Vitousek, P. M., Cassman, K. G., Matson, P. A., Bai, J. S., ... Zhang, F. S. (2011). Integrated soilcrop system management for food security. Proceedings of the National Academy of Sciences of the United States of America. https://doi.org/10.1073/pnas.1101419108

[4] Creswell, J. (2013). Qualitative, quantitative, and mixed methods approaches. In Research design.

[5] Dayan, F. E., Cantrell, C. L., \& Duke, S. O. (2009). Natural products in crop protection. Bioorganic and Medicinal Chemistry. https://doi.org/10.1016/j.bmc.2009.01.046

[6] Devi Juwaheer, T., Pudaruth, S., \& Monique Emmanuelle Noyaux, M. (2012). Analysing the impact of green marketing strategies on consumer purchasing patterns in Mauritius. World Journal of Entrepreneurship, Management and Sustainable Development. https://doi.org/10.1108/204259612112216 15

[7] El Bilali, H., Bassole, I. H. N., Dambo, L., \& Berjan, S. (2020). Climate change and food security. Agriculture and Forestry. https://doi.org/10.17707/AgricultForest.66. 3.16

[8] Hannah, L., Roehrdanz, P. R., Ikegami, M., Shepard, A. V., Shaw, M. R., Tabor, G., ... Hijmans, R. J. (2013). Climate change, wine, and conservation. Proceedings of the National Academy of Sciences of the United States of America. https://doi.org/10.1073/pnas.1210127110

[9] Meriam, A. (2019). Analisis Pengaruh Firm Size, Risiko Bisnis, dan Risiko Keuangan Terhadap Tingkat Keuntungan. Jemma Jurnal of Economic, Management and Accounting, 2(1), 102-113.

[10] Muller, A., Schader, C., El-Hage Scialabba, N., Brüggemann, J., Isensee, A., Erb, K. H., ... Niggli, U. (2017). Strategies for feeding the world more sustainably with organic agriculture. Nature Communications. https://doi.org/10.1038/s41467-01701410-w

[11] Palacios-Lopez, A., Christiaensen, L., \& Kilic, T. (2017). How much of the labor in 
African agriculture is provided by women? Food Policy. https://doi.org/10.1016/j.foodpol.2016.09. 017

[12] Ponto, J. . ., Benu, N. M., \& Kumaat, R. M. (2017). Upsus Pajale Dalam Menunjang Program Swasembada Pangan Di Kabupaten Bolaang Mongondow. AgriSosioekonomi. https://doi.org/10.35791/agrsosek.13.2a.20 17.17017

[13] Rachman, S., Hamiru, H., Umanailo, M. C. B., Yulismayanti, Y., \& Harziko, H. (2019). Semiotic Analysis of Indigenous Fashion in The Island of Buru. International Journal Of Scientific \& Technology Research, 8(8), 1515-1519.

[14] Rahmat, A., Gs, A. D., Djafri, N., Shofwan, I., \& Umanailo, M. C. B. (2019). The Influence of Family Leadership towards Adolescent Social Values in the City of Gorontalo. International Journal Of Scientific \& Technology Research, 8(10).

[15] Romlah, S. N., Pratiwi, R. D., Indah, F. P. S., \& Umanailo, M. C. B. (2020). Qualitative study factors triggering gay characteristics in gay groups in Palmerah District West Jakarta. Proceedings of the International Conference on Industrial Engineering and Operations Management.

[16] Tahir, S. Z. A. Bin, \& Umanailo, M. C. B. (2019). Consumption Culture of Namlea Communities. Proceedings of the International Conference on Industrial Engineering and Operations Management Riyadh, Saudi Arabia, 974-978. Riyadh, Saudi Arabia: IEOM Society International.

[17] Tilman, D., Balzer, C., Hill, J., \& Befort, B. L. (2011). Global food demand and the sustainable intensification of agriculture. Proceedings of the National Academy of Sciences of the United States of America. https://doi.org/10.1073/pnas.1116437108

[18] Umanailo, M. C. B. (2020). Dominance of Economic Capital. International Journal Of Scientific \& Technology Research Volume, 9(01), 1-4.
[19] Umanailo, M. C. B., \& Ali, A. (2019). The limited use of information technology on services and learning at Iqra Buru University. Proceedings of the International Conference on Industrial Engineering and Operations Management, 1133-1139. Toronto, Canada.

[20] Umanailo, M. C. B., Yulisvestra, M., Oki, K. K., Mulyasari, W., \& Ridwan, R. (2019). The Thought of Emile Durkheim in the Contestation of Development in Indonesia. International Journal Of Scientific \& Technology Research, 8(8), 1881-1885.

[21] Zhang, X., Davidson, E. A., Mauzerall, D. L., Searchinger, T. D., Dumas, P., \& Shen, Y. (2015). Managing nitrogen for sustainable development. Nature. https://doi.org/10.1038/nature15743

[22] Zhao, M., \& Hannum, E. (2019). Stark Choices: Work-Family Tradeoffs among Migrant Women and Men in Urban China. Chinese Sociological Review. https://doi.org/10.1080/21620555.2019.16 35879

[23] Zhong, T. Y., Huang, X. J., Zhang, X. Y., \& Wang, K. (2011). Temporal and spatial variability of agricultural land loss in relation to policy and accessibility in a low hilly region of southeast China. Land Use Policy. https://doi.org/10.1016/j.landusepol.2011. 01.004 